\title{
A New Mass and its Implications for Gaspar's Late Mass Style
}

\author{
Paul Kolb
}

\begin{abstract}
$\mathrm{C}$
ompared to Gaspar's three motet Cycles, his surviving output of conventional mass cycles is significantly larger. But these masses have received comparably little scholarly attention. The existing literature consists primarily of two dissertations: the unpublished dissertation of Werner Wegner from 1940 on the Missa O Venus bant, and that of Eric Fiedler, published in 1997 as Die Messen des Gaspar van Weerbeke. The long-awaited publication of Gaspar's masses in edition provides the opportunity to re-examine this repertory in context. ${ }^{2}$

There are eight surviving complete masses and two independent Credo settings with clear contemporary attributions to Gaspar. The Missae Ave regina celorum and O Venus bant, surviving in $\mathrm{CS}_{\text {I4 }}$ and ${ }_{51}$ respectively, date from before Gaspar joined the papal chapel in I48I. $^{3}$ At the time of composition, Gaspar would have been in his mid- to late twenties, a young Fleming in Milan, composing ambitious works and ambitiously promoting them beyond the confines of the city. The two masses surviving in CS 35, the Missae Se mieulx ne vient and Princesse d'amourettes, were probably composed in the I 480 s while Gaspar was a member of the papal chapel. ${ }^{4}$ The Missa Et trop penser may also date from this decade, even though its earliest source, CS 4I, was copied somewhat later. ${ }^{5}$ Whether or not these masses were composed in Rome, they quickly became part of the repertoire of the papal chapel. Despite some striking aspects, they all fit within the contemporary tradition of cantus-firmus masses. All of these masses survive additionally in later sources, and the Missa O Venus bant is one of the most widely transmitted masses of the fifteenth century.
\end{abstract}

See Eric F. Fiedler, Die Messen des Gaspar van Weerbeke (ca. 1445-nach 1517), Frankfurter Beiträge zur Musikwissenschaft, 26 (Tutzing: Hans Schneider, 1997). Werner Wegner's dissertation at the University of Marburg was never published as he did not survive the Second World War. It consists primarily of a tenorbased analysis of the Missa O Venus bant. The submitted manuscript can be found in the Marburg University Archives under the signature UniA MR 307 d Nr. 262I.

$2 \quad$ Weerbeke, $C W_{\mathrm{I}}$ : Masses I, ed. Pavanello and Lindmayr-Brandl, and $C W_{2}$ : Masses 2, ed. Kolb and LindmayrBrandl. In some of what follows, I am summarizing or elaborating on arguments already put forth in my introduction to the latter volume.

3 See Weerbeke, $C W_{\mathrm{I}}$, pp. xxi-xxvii, and the literature cited therein.

See ibid., pp. xxvii-xxix.

See Weerbeke, $C W_{2}$, p. xxii. 
The two Credo settings survive together in Petrucci's 1505 Fragmenta missarum. In addition, the unnamed Credo was copied towards the end of CS $5^{\mathrm{I}}$ and thus dates from the early I 480 s at the latest. There are no further sources of the Credo cardinale, but there is little to suggest that this second Credo was not also composed significantly earlier than the print date. ${ }^{6}$ While there is much that connects the style of these works to Gaspar's complete mass settings, they were almost certainly composed as single mass movements. In addition to being found in Petrucci's print Fragmenta missarum, which transmits almost exclusively independently composed movements, there are a few musical indications of this, including the use of a plainchant Credo melody in the Credo cardinale and the avoidance of sections with reduced texture in both settings. ${ }^{7}$

The remaining masses, like the earlier cycles, set the complete text of the Roman mass ordinary in five movements. Otherwise they stand out from Gaspar's other masses: there are no clear connections to Rome, none of them uses a tenor cantus firmus, and the transmission is fairly sparse. The Missa octavi toni survives in three complete and independent sources, the earliest of which-Jena 3I-probably dates from the final years of the fifteenth century. The Missa N'as tu pas survives complete only in a Petrucci print: not the 1507 Misse Gaspar but instead the 1508 anthology Missarum diversorum auctorum. This might suggest that Petrucci had access to the mass only after the 1507 print was completed. ${ }^{8}$ Finally, the Missa brevis survives uniquely in Jena 21, an Alamire source probably dating from the early 1520s. ${ }^{9}$ Following Fiedler, the Missa octavi toni was probably composed in the r 490 os and the Missa N'as tu pas in the first decade of the sixteenth century. ${ }^{10}$ Based on stylistic similarities, the Missa brevis very well may date from around the same time as the Missa N'as tu pas. Despite my tentative dating of these last two masses to a period in which Gaspar was at the papal chapel, there is little evidence of a performance tradition of these late masses in either Rome or Milan.

Two of these masses are not based on a pre-existing chant or song. The titles 'octavi toni' and 'brevis' are reminiscent of the labels given by Franchinus Gaffurius in the Milanese codices, and they more generally reflect Petrucci's practice of assigning names to the masses he published. ${ }^{11}$ Whereas 'octavi toni' references the mode in which the mass was composed,

6 See Weerbeke, $C W_{2}$ 2, pp. xxv-xxvi.

7 Petrucci's print does include a three-movement Missa ferialis, but including this mass, none of the compositions is found elsewhere in more complete versions. See Weerbeke, $C W_{2}$, p. xxv. Of course, neither of the mentioned indications is conclusive. Two of Gaspar's securely attributed masses, as well as the new mass discussed below, avoid reduced texture altogether, and the new mass also uses portions of a plainchant Credo as a brief cantus firmus.

8 On the other hand, as Andrea Lindmayr-Brandl pointed out to me, Petrucci probably would not have added the sixth mass to the collection even if he had had access to it. Petrucci's mass collections most often included five masses each, spread out over seven or eight gatherings (quaternions or quinterns); Misse Gaspar already filled out the available space. See Stanley Boorman, Ottaviano Petrucci: A Catalogue Raisonné (New York and Oxford: Oxford University Press, 2006), 154 and 640-45. It is possible that the Missa N'as tu pas was collected along with the other Gaspar masses but was only able to be used in the anthology the following year.

9 On these three masses, see Weerbeke, $C W_{2}$, pp. xxii-xxv.

Io Fiedler, Die Messen des Gaspar van Weerbeke, roo-I and ro9-I3.

II See Honey Meconi, 'Petrucci's Mass Prints and the Naming of Things', in Venezia r5or: Petrucci e la stampa musicale /Venice I5or: Petrucci, Music, Print and Publishing, ed. Giulio Cattin and Patrizia Dalla Vecchia, ser. III, Studi musicologici B, Atti di Convegni, 6 (Venice: Fondazione Levi, 2005), 397-4I4. 
'brevis' apparently refers to the brief length of the composition. ${ }^{12}$ While the Missa octavi toni is similar in length to the earlier masses, the Missae N'as tu pas and Brevis are both significantly shorter-but N'as tu pas, based on pre-existing musical material, did not require a new label. ${ }^{13}$

Gaspar's Missa brevis was one of several masses from the late fifteenth and early sixteenth centuries with the same title. Despite its late transmission in a single manuscript, among the masses therein it is not notably short: the title was probably taken from its exemplar and may even date back to its composition. Most of the other instances are found in the Gaffurius codices, Milan 2 and 3. Adelyn Peck Leverett argued that these Missae breves formed a stylistically differentiated subgenre originating from (if not unique to) Milan, with common musical characteristics including syllabic text setting, shortened texts of the Gloria and Credo, a common head-motif, and a single mensuration used throughout. ${ }^{14}$ Some of these characteristics might also be described as strategies for composing a short mass. Fiedler added Gaspar's Missa brevis to the discussion, arguing that the Missae breves of Gaffurius, Compère, and Gaspar all emphasize the careful division of text into homophonic sections and short, paired duets, especially within the Glorias and Credos. ${ }^{15}$ The Missa N'as tu pas, as a mass of similar length, should also be placed under consideration, even though it is based on preexisting musical material. ${ }^{16}$

While the Missae brevis and N'as tu pas both share certain of the stylistic elements common to Leverett's supposed subgenre of 'missae breves', these masses are not nearly as short as those by Gaffurius, nor are their musical features quite so straightforward. But before discussing these in detail, another mass needs to be added to the picture. This mass, given no title, shares much in common with the Missae brevis and N'as tu pas and also has similarities to the Missa octavi toni and the Credo cardinale. And it is probably also the work of our composer.

\section{The Missa Une mousse de Biscaye}

The repertory of masses composed by Gaspar has remained stable since Gerhard Croll first published a list of Gaspar's works in $1952 .{ }^{17}$ But there has been one proposed addition: Jaap van Benthem has suggested that the Missa Une mousse de Biscaye, included in Petrucci's 1505 Missarum Josquin liber secundus and also attributed to Josquin in its two manuscript sources, may have actually been composed by Gaspar. ${ }^{18}$ Van Benthem was in fact one of the first to

I2 The title 'octavi toni' is first associated with this mass in the Petrucci print, and among later sources it is only found in those which are dependent on Petrucci. It seems unlikely that Gaspar was intentionally composing a mass 'in the eighth mode' as such; rather, Petrucci's editor presumably added what he considered to be an appropriate label.

I3 Fiedler, Die Messen des Gaspar van Weerbeke, II4, compiled a chart with the number of bars (breves) in each movement of each mass. Comparisons on this basis are not altogether unproblematic, but there is nevertheless a significant difference between the total lengths of these two masses as compared to the other six.

I4 Adelyn Peck Leverett, 'An Early Missa brevis in Trent Codex 9I', in Music in the German Renaissance: Sources, Styles, and Context, ed. John Kmetz (Cambridge: Cambridge University Press, 1994), 152-73.

I5 Fiedler, Die Messen des Gaspar van Weerbeke, II3-25.

I6 As comparable instances, Leverett also mentions Josquin's Missa D'ung aultre amer and Martini's Missa In Feuers Hitz as belonging to the compositional phenomenon of the 'missa brevis' ('An Early Missa brevis', r69-70).

I7 Gerhard Croll, 'Gaspar van Weerbeke: An Outline of his Life and Works', Musica Disciplina, 6 (1952), 67-8I.

I8 Jaap van Benthem, 'Was "Une mousse de Biscaye" Really Appreciated by L'ami Baudichon?', Muziek und Wetenschap, I (1991/1992), I75-94, at 184-85. Thanks to Professor van Benthem for providing a copy of his article. 


\section{Paul Kolb}

argue that the mass was not by Josquin. ${ }^{19}$ Among other things, the mass's sources all share numerous apparent errors. They may ultimately derive from the same exemplar, whose scribe could have confused the attribution with that of Josquin's four-voice song, Une mousse de Biscaye. ${ }^{20}$ For van Benthem, the lack of an independent Agnus dei and curiosities in the textual composition of the Benedictus suggest that it may have originally been an Ambrosian mass, which was then modified for use in the Roman rite. ${ }^{21}$ Finally, its style does not resemble other early Josquin compositions. Instead, van Benthem posits numerous stylistic connections between the mass and compositions by Gaspar:

Missa Une mousse de Biscaye is characterized by unsystematic, rather loose motivic interplay between the voices, an overall presence of minima against minima counterpoint in which the inner voices lose their individuality, and by phrases built up in a succession of (mainly) short-term impulses....

But also compositorial details in Missa Une mousse de Biscaye, like various types of short and isolated dissonant clashes, ... strikingly match general tendencies in Gaspar's counterpoint. The same can be said of some rather primitive, parallel motion between the voices, including a particular cadential formula standing out by a parallel fifth between the Superius and Altus. ${ }^{22}$

Scholars have responded to this with varying degrees of enthusiasm. Fiedler pointed to numerous differences in style between the Missa Une mousse and Gaspar's other surviving masses, especially those concerning overall textural/structural design and cantus-firmus treatment. He concluded by saying, 'we must assess the chance of Gaspar's authorship as being rather small'. ${ }^{23}$ Fabrice Fitch (in Ch. 7 above) considers the cantus-firmus treatment and contrapuntal clumsiness to speak against authorship by either composer. ${ }^{24}$ The remaining responses only questioned whether the mass was composed by Josquin. Anne-Emmanuelle Ceulemans argued that the parallel intervals, voice-leading, dissonance treatment, and certain cadential features found in the Missa Une mousse are uncommon in other compositions of Josquin; together they point towards misattribution. ${ }^{25}$ Rob C. Wegman, on the other hand, challenged this sort of stylistic attributive research on methodological grounds, arguing that, based on the strength of the contemporary attributions, the Missa Une mousse 'must count as one of the most solidly attested in the Josquin canon'. ${ }^{26}$ Despite suggesting that the young Josquin

I9 Jeremy Noble, 'Josquin des Prez', in The New Grove Dictionary of Music and Musicians, ed. Stanley Sadie (London: MacMillan, 1980), vol. 9, pp. 713-38, at 724, had previously discussed the problem of its attribution, arguing that it could only be accepted as an early work of Josquin's. This is cited in van Benthem, 'Was "Une mousse de Biscaye"', I78.

20 Van Benthem, 'Was "Une mousse de Biscaye", I77 and I89-90.

Ibid., I77-84.

Ibid., I84-85.

Eric F. Fiedler, 'A New Mass by Gaspar van Weerbeke? Thoughts on Comparative Analysis', in Studien zur Musikgeschichte: Eine Festschrift für Ludwig Finscher, ed. Annegrit Laubenthal (Kassel: Bärenreiter, 1995), $72-87$, quote at 87 .

24 Fitch, Ch. 7, n. 26.

25 Anne-Emmanuelle Ceulemans, 'A Stylistic Investigation of Missa Une mousse de Biscaye in the Light of its Attribution to Josquin des Prez', Tijdschrift van de Koninklijke Vereniging voor Nederlandse Muziekgeschiedenis, 48 (1998), 30-50.

26 Rob C. Wegman, 'Who was Josquin?', in The Josquin Companion, ed. Richard Sherr (New York and Oxford: Oxford University Press, 2000), 2I-50, at 30. 
might have wanted to compose a mass emulating Gaspar's style, David Fallows was unable to convince himself that Josquin composed this mass: 'logic aside, it simply feels to be wrong'. ${ }^{27}$ In the New Josquin Edition, Martin Just analysed all of the stylistic arguments and found the attribution to Josquin justifiable, suggesting that Josquin may have instead used the masses of Ockeghem as a model. ${ }^{28}$

To add a couple of minor points, there are some features of the Missa Une mousse which are reminiscent of the masses of Gaspar. The voice ranges, while not unusual at the time, are more typical of Gaspar than Josquin. ${ }^{29}$ The cadences also share certain features commonly used by Gaspar..$^{30}$ As van Benthem already suggested, Gaspar's imitation (or 'motivic interplay') is indeed often 'unsystematic', if no less compelling for that reason. Certain dissonances, for example between passing semiminims, were part of his musical vocabulary. Quickly alternating sonorities, as in bar $\mathrm{I} 28$ of the Gloria, are particularly characteristic. There are some striking modal shifts which might be considered unusual for Gaspar, but these derive quite clearly from the nature of the pre-existing melody. ${ }^{31}$

All of this being said, I remain unconvinced that the musical style really resembles Gaspar. Perhaps significantly, the Missa Une mousse contains a surprising number of accented sixth chords within three- or four-voice texture which are neither suspensions nor part of a cadence, often without the third in another voice. ${ }^{32}$ Such instances in other Gaspar masses are relatively rare. Overall, if this mass had survived with contemporary attributions to Gaspar instead of Josquin, stylistic analysis would not immediately cause one to question the attribution: indeed, resonances with other well-attested works, such as those in van Benthem's examples, would give one the impression of being on solid ground. But even if one were inclined to reject the clear contemporary attributions to Josquin, the musical style would not unilaterally point to Gaspar as a replacement.

\section{A Mass Pair in Jena 2I}

For our new mass, then, we must look elsewhere. Consisting exclusively of eight masses, the Alamire manuscript Jena 2I was probably copied for the court chapel of Frederick the Wise around the early $1520{ }^{33}$ The copying thus took place shortly after the deaths of Matthaeus

27 David Fallows, Josquin (Turnhout: Brepols, 2009), 268.

28 NJE 5: Masses Based on Secular Monophonic Songs I, ed. Just, critical commentary, 79-89.

29 Numerous exceptions aside, Gaspar's tenor lines tend not to have the high upper register of his alto lines.

30 Gaspar's cadences almost always rearticulate any common tones, as often happens in the Missa Une mousse. There are also frequent cadences we might anachronistically call 'deceptive', where the bass resolves to the third, not the octave, below the tenor.

3I Specifically, the movements of the mass generally start on F, have numerous internal cadences on $\mathrm{G}$ or F, but finish with a final cadence on $\mathrm{B} b$ - all of which are characteristics of the song. All of Gaspar's complete masses and motet cycles have a final of either F (with Bb signature) or $\mathrm{G}$ (with or without $\mathrm{B}$ b signature), though his individual motets have somewhat more variety.

32 In the Credo alone, see bb. I8, 30, I03-5, II7, I43, I50, I5I, I80, and I8I-82, as in NJE 5, pp. 45-58.

33 Herbert Kellman, 'Josquin and the Courts of the Netherlands and France: The Evidence of the Sources', in Josquin des Prez: Proceedings of the International Josquin Festival-Conference Held at the Juilliard School at Lincoln Center in New York City, 2I-25 June I97I, ed. Edward E. Lowinsky and Bonnie J. Blackburn (London: Oxford University Press, I976), I8I-2I6, at 213. This was confirmed by Eric Jas in The Treasury of Petrus Alamire: Music and Art in Flemish Court Manuscripts, 1500-1535, ed. Herbert Kellman (Ghent and Amsterdam: Ludion, 
Pipelare, Pierre de la Rue, Josquin, and Gaspar, all of whom are represented musically in the mansucript. Five of the masses, including Gaspar's Missa brevis, survive completely only in this source; the exceptions are Josquin's Missa Pange lingua, Pipelare's Missa de feria, and the Missa Allez regretz attributed to 'Io. de pratis'. Perhaps surprisingly given his Flemish origins, unlike the other named composers Gaspar is poorly represented in the Alamire choirbooks; the Missa brevis is a rare exception. ${ }^{34}$

The first seven masses in Jena 2I almost all have both an attribution and a title or an identification of the cantus firmus in red ink. The opening mass, Josquin's Missa Pange lingua, labelled 'Missa de venerabili sacramento', does not have an attribution, but the mass was well known among the Alamire scribes and Josquin's authorship was probably taken for granted (see Figure II.I). The seventh mass is Gaspar's Missa brevis, given the red header 'Missa brevis iaspar'. This is followed by an unnamed, anonymous mass (see Figure II.2). In this context, the first opening of this final mass is striking for its lack of red ink or indications of any kind, whether giving the name of the composer, a title for the mass, or the source of the cantus firmus. ${ }^{35}$

The anonymous mass was transcribed and discussed extensively by Zoe Saunders, who suggested Martini, Compère, and indeed Gaspar as possible composers. ${ }^{36}$ But the stylistic arguments in favour of Gaspar are by far the strongest. More specifically, the mass forms a compositional pair with the mass that precedes it in the manuscript, Gaspar's Missa brevii. ${ }^{37}$ Finally, as will be discussed later, a cut-off inscription appears to confirm that Gaspar was the composer.

On a structural level, the mass shares specific and unique details of design which are common to the late masses of Gaspar. Like the Missae brevis, N'as tu pas, and octavi toni, the Sanctus is in three self-contained sections, with two different Osannas following continuously from the Pleni sunt and Benedictus. These are the only four masses that I know by any composer which do this in precisely this manner. ${ }^{38}$ Other details of textual structure are also identical if more generally common. There are three separate sections of the Kyrie and Agnus,

I999), ro3. While Kellman posited a terminus post quem of I52I based on a cross next to the name 'Io. de pratis', this only holds if the attribution can be identified with Josquin; see Zoe Saunders, 'Anonymous Masses in the Alamire Manuscripts: Towards a New Understanding of a Repertoire, an Atelier, and a Renaissance Court' (Ph.D. diss., University of Maryland, 20I0), 8I-92.

34 See e.g. Treasury of Petrus Alamire, i74.

35 There appear to have been at least two hands at work in the manuscript. The scribe who copied Josquin's Missa Pange lingua, as in Figure Ir.I, may also have copied Pierre de la Rue's Missa Sancta Dei genitrix. A different scribe copied the remainder of the manuscript, including both Gaspar's Missa brevis and the anonymous mass, as in Figure ir.2.

36 Saunders, 'Anonymous Masses in the Alamire Manuscripts', 65-93.

37 See Weerbeke, $C W_{2}$, pp. I43-70, for a complete edition of the mass, included in the appendix to the volume as an 'opus dubium' under the title Missa [sine nomine].

$3^{8}$ Pipelare's Missa de feria in this manuscript is similar, though the Benedictus is split into three sections (Benedictus, Qui venit, and In nomine domini. Osanna in excelsis). Some of Gaffurius's masses also share certain similarities: in the Missa sexti toni irregularis, for example, there are two different Osannas which continue without barline from the Pleni sunt and Benedictus duets. Nevertheless, these both follow clear cadences and begin with four-voice, chordal Osannas with fermatas. The first version of the Sanctus in his Missa brevis octavi toni is completely through-composed, though with semibreve rests in all voices before the Benedictus. See Franchinus Gaffurius, Messe, ed. Amerigo Bortone, Archivium Musices Metropolitanum Mediolanense, I-3 (Milan, I958-60), vol. I, pp. 7I-74 or vol. 2, pp. I30-34, and vol. 3, pp. Io8-II. On the other hand, there are no comparable examples in the surviving output of Josquin or Compère, for example. 
which is true of all other masses by Gaspar. Gaspar's settings of the Gloria and Credo are remarkably inconsistent in the way that they divide the text; nevertheless, this Gloria is divided into two sections in the same way as the Missa Ave regina celorum and, again, the Missa brevis. There is no exact corollary to the text division of this mass's Credo, but it is similar to the Missa brevis and Missa N'as tu pas. ${ }^{39}$

While there are numerous short duets within individual sections of this mass and longer duets at the beginning of the Benedictus, there are no complete sections with reduced texture. This is again common in Gaspar's late masses, specifically the Missa brevis and Missa N'as tu pas. ${ }^{40}$ Like both of these masses, the essential mensuration is $\phi$, with brief triple sections (most commonly notated as $\$ 3$ ) at the end of some of the longer movements. This is not unusual, but it adds to the list of commonalities in these masses. ${ }^{41}$

Unlike Gaspar's other known masses, this mass references multiple pre-existing melodies. The beginning of the Gloria includes very brief resonances of the songs De tous biens plaine and La morra, while the Credo quotes two portions of a Credo chant melody. ${ }^{42}$ The chant quotations have their main statement in the superius or tenor with imitation in the other voices, not unlike the complete citation of a different Credo chant in the Credo cardinale. Nevertheless, the use of multiple pre-existing sources of musical material, all so briefly, is unusual in the mass repertory as a whole.

If general structural aspects are compatible with Gaspar's other masses, stylistic aspects found in this mass are characteristic of his later masses specifically. Among those, the anonymous mass and the Missa brevis form a textural and contrapuntal pair. In the Kyrie, for instance, both masses begin in full texture with an identical chord. The Christe and second Kyrie begin with brief imitation in all voices, though the entrances are slightly closer in the latter section. The imitation found throughout the anonymous mass is, to use van Benthem's words, 'unsystematic' and 'rather loose': phrase openings will often imitate or resemble those in another voice, but these similarities are almost always short-lived. Some of the only more extensive imitation occurs at the beginning of the Benedictus; the same occurs at the corresponding location of the Missa brevis. In both of these cases, the Benedictus begins with an imitative duet, and the Qui venit begins with an imitative duet in the other two voices. Contrapuntally, the cadences tend to have features typical of Gaspar. ${ }^{43}$ And as in Gaspar's other masses, the counterpoint here might be described as reliable if not particularly adventurous or elegant. ${ }^{44}$

Given the similar lengths and compositional techniques used, the anonymous mass might reasonably be considered another 'missa brevis'. In both masses, the Glorias and Credos almost exclusively use syllabic text-setting; the readings in Jena $2 \mathrm{I}$ are particularly clear in this regard. Both Glorias begin in four-voice texture (again, with an identical chord); this eventually

39 For the sake of comparison, there are no corollaries amongst the known masses of Weerbeke to the textual division of the Gloria or Credo in Missa Une mousse, nor is there a comparable instance of 'Agnus dei super Kyrie'.

40 This is also true of both independent Credo settings and most of the Missa octavi toni, as well as, incidentally, the Missa Une mousse.

4I In the Missa brevis $\mathrm{C}_{2}$ is used interchangeably with $\phi$, apparently to signify interior sections of movements.

42 These are discussed in more detail at Weerbeke, $C W_{2}$, p. xci.

43 See above, n. 30.

44 Certain duets are even rather banal; see especially the Credo, bb. 44-54. 


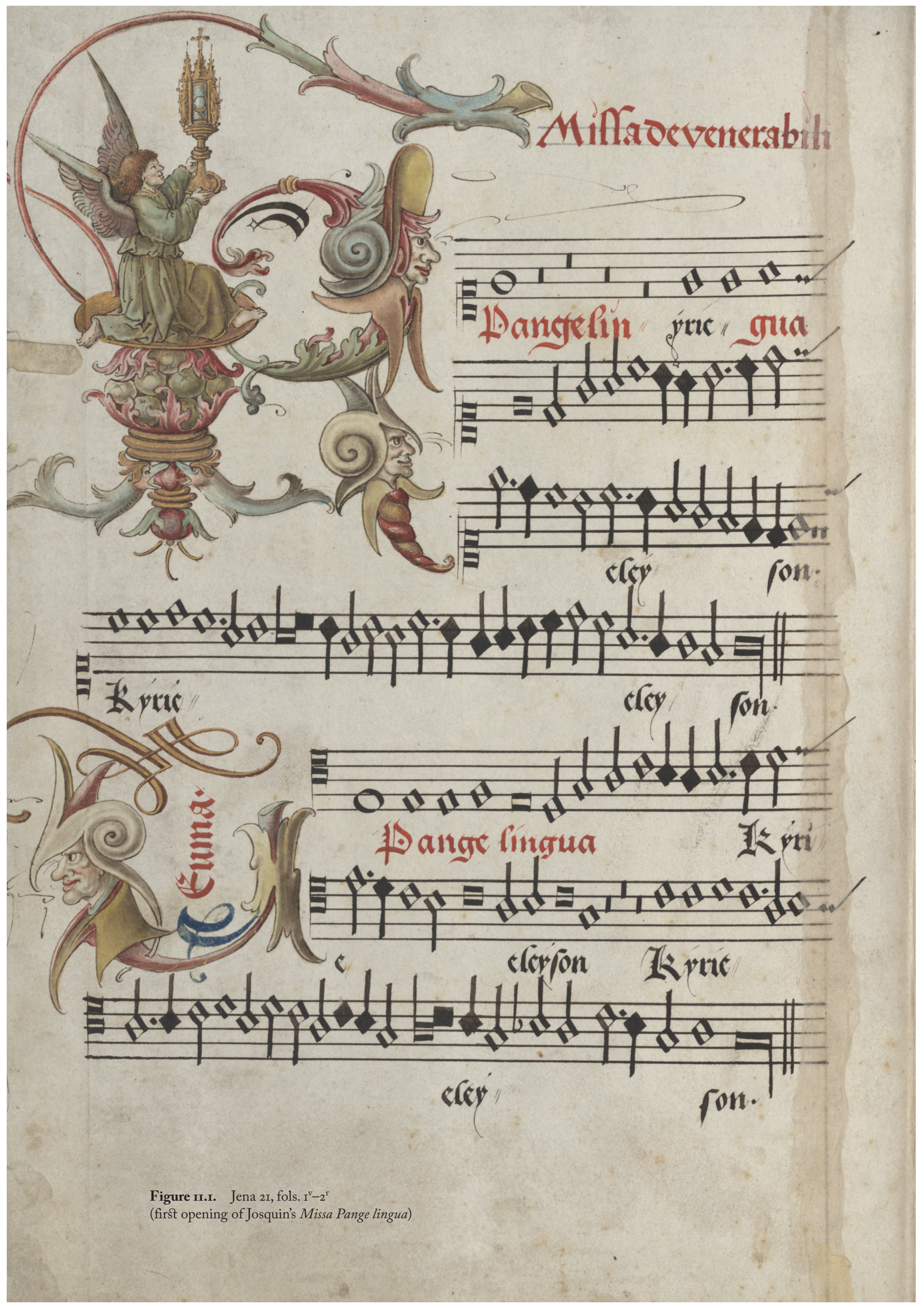




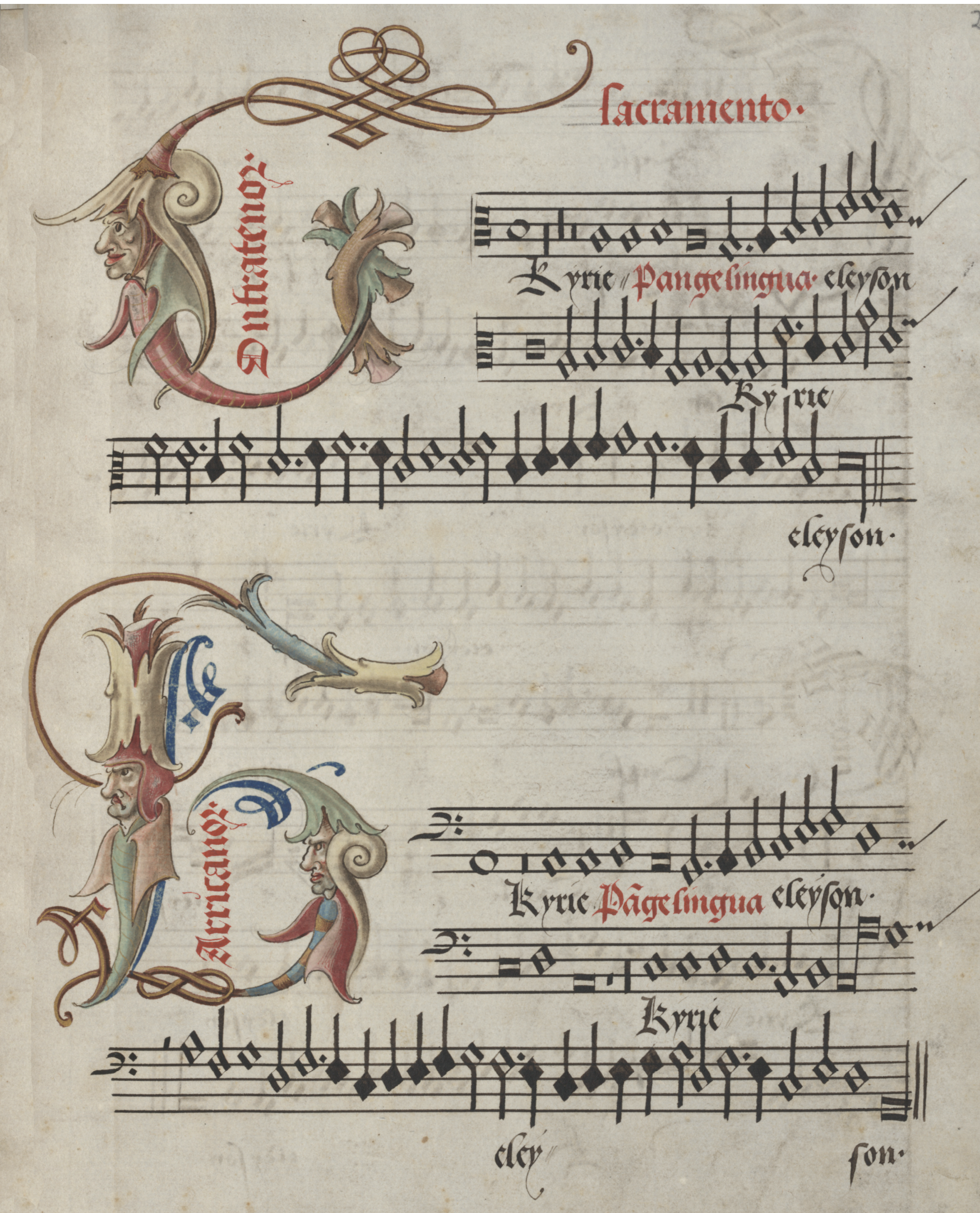




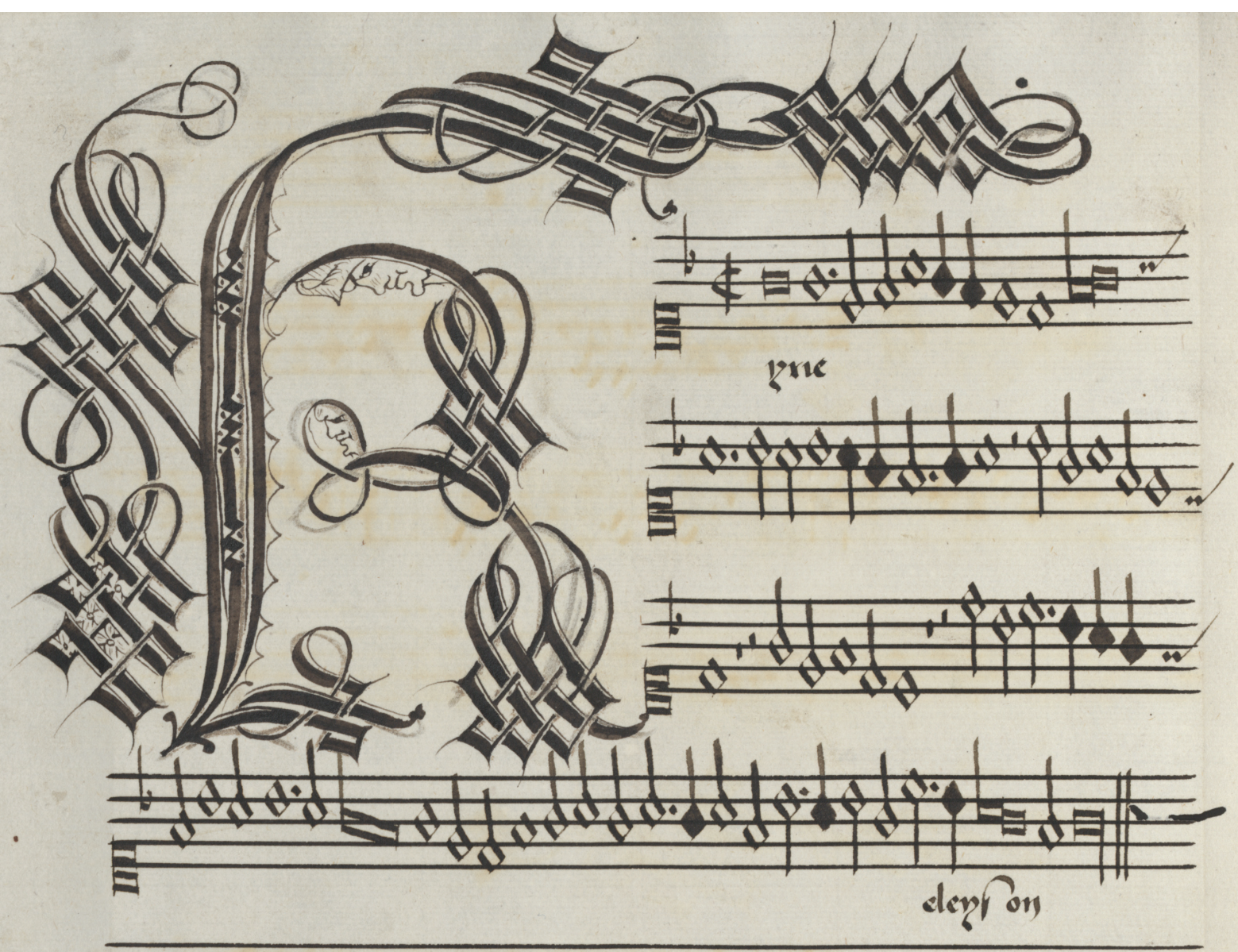

(ID) +

SIV

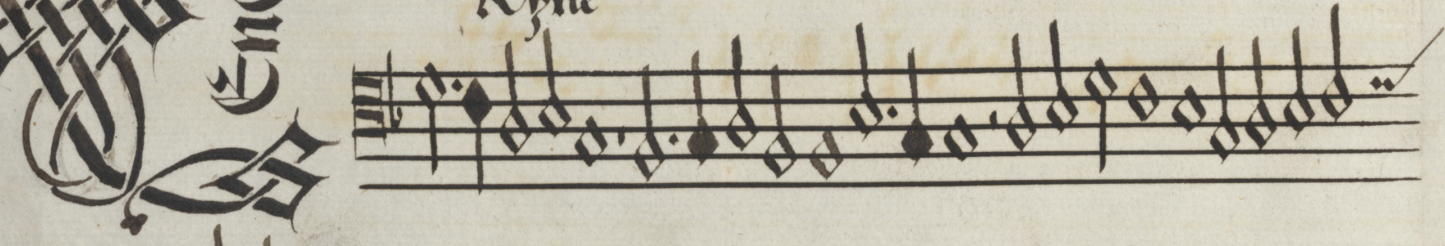

+ky

Figure II.2. Jena 2I, fols. $\mathrm{IOI}^{\mathrm{V}-\mathrm{IO}^{\mathrm{r}}}$

(first opening of the Missa [sine nomine]) 


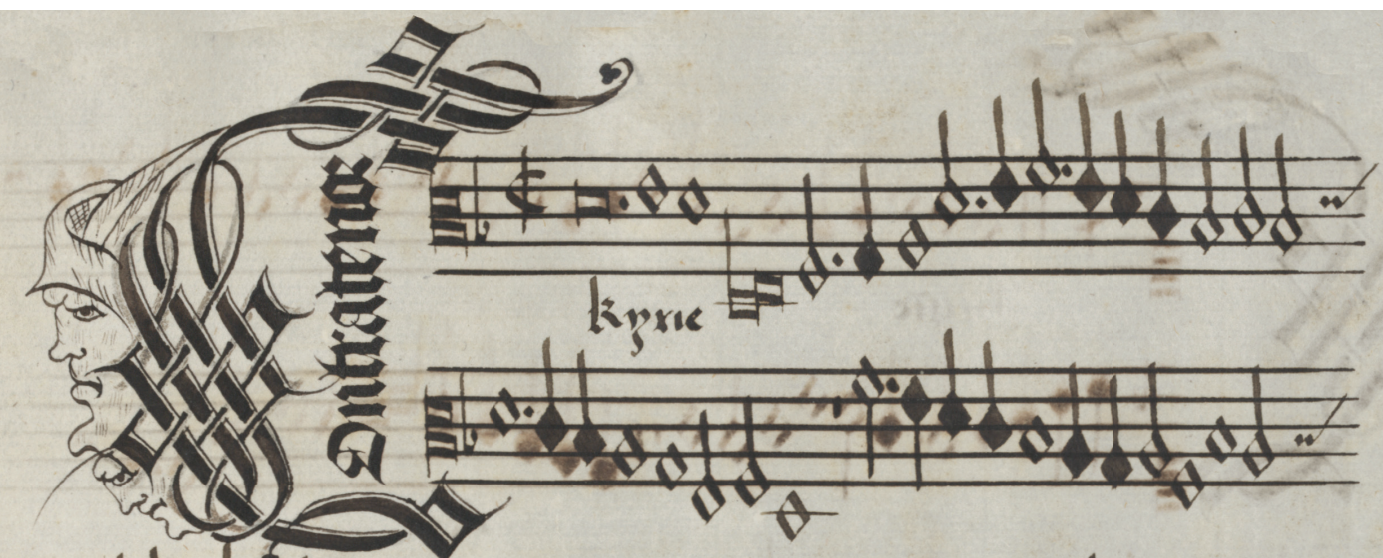

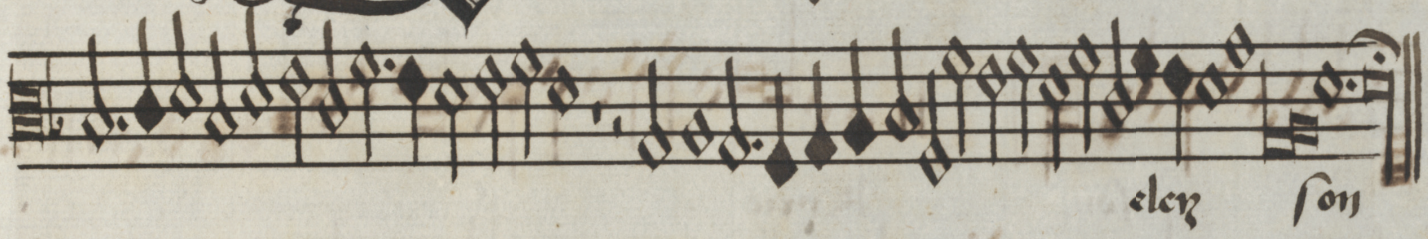
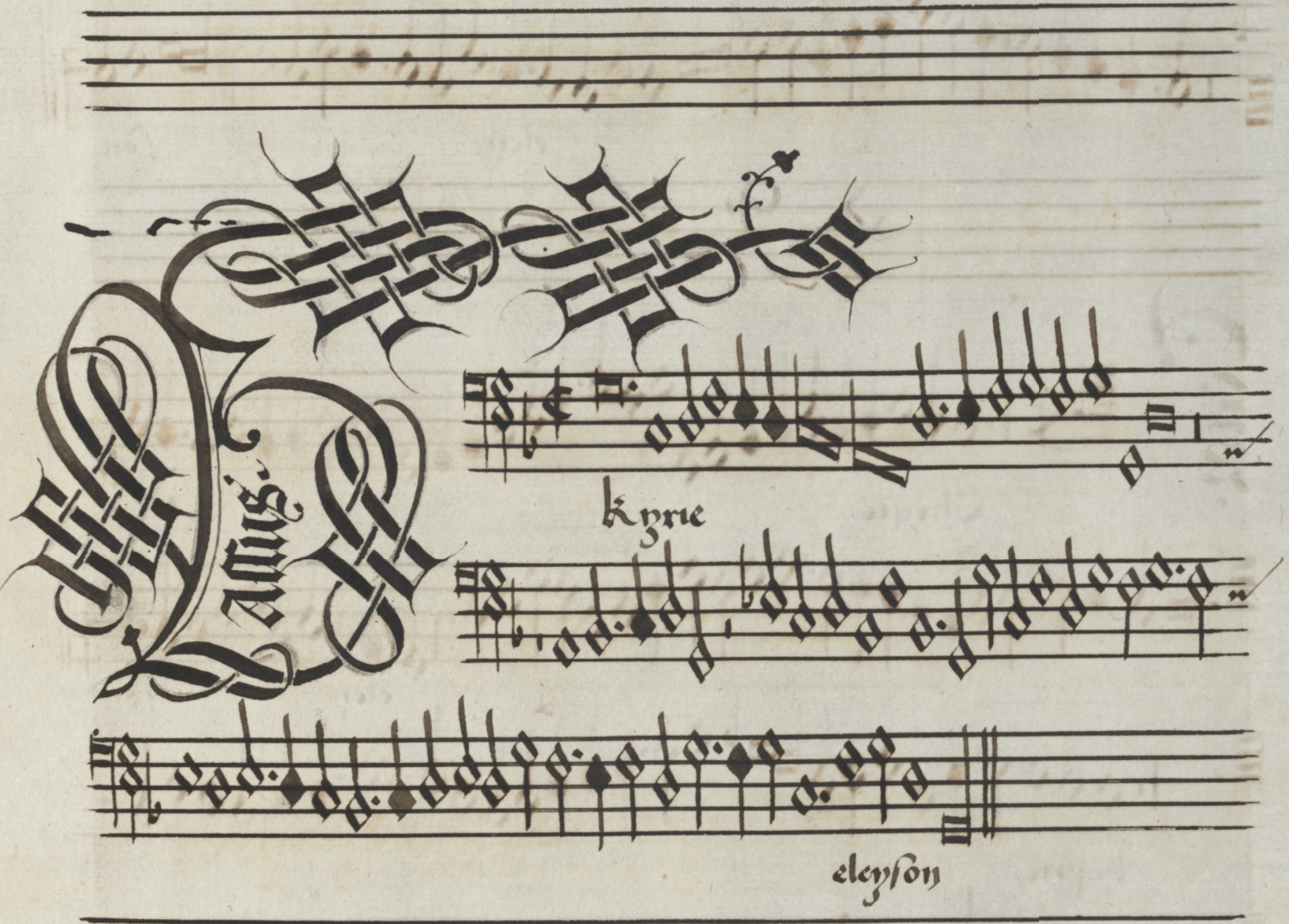


\section{Paul Kolb}

devolves into a series of paired duos, returning to full texture at (or shortly in advance of) 'Jesu Christe'. In the Qui tollis sections which follow, the alternation of full texture and duets occurs over the same text phrases. The full-texture sections are often homophonic, repeating or alternating between sonorities at the level of the minim or semibreve (see Example II.I).

Example Ir.I. (a) Missa [sine nomine], Gloria bb. 49-63
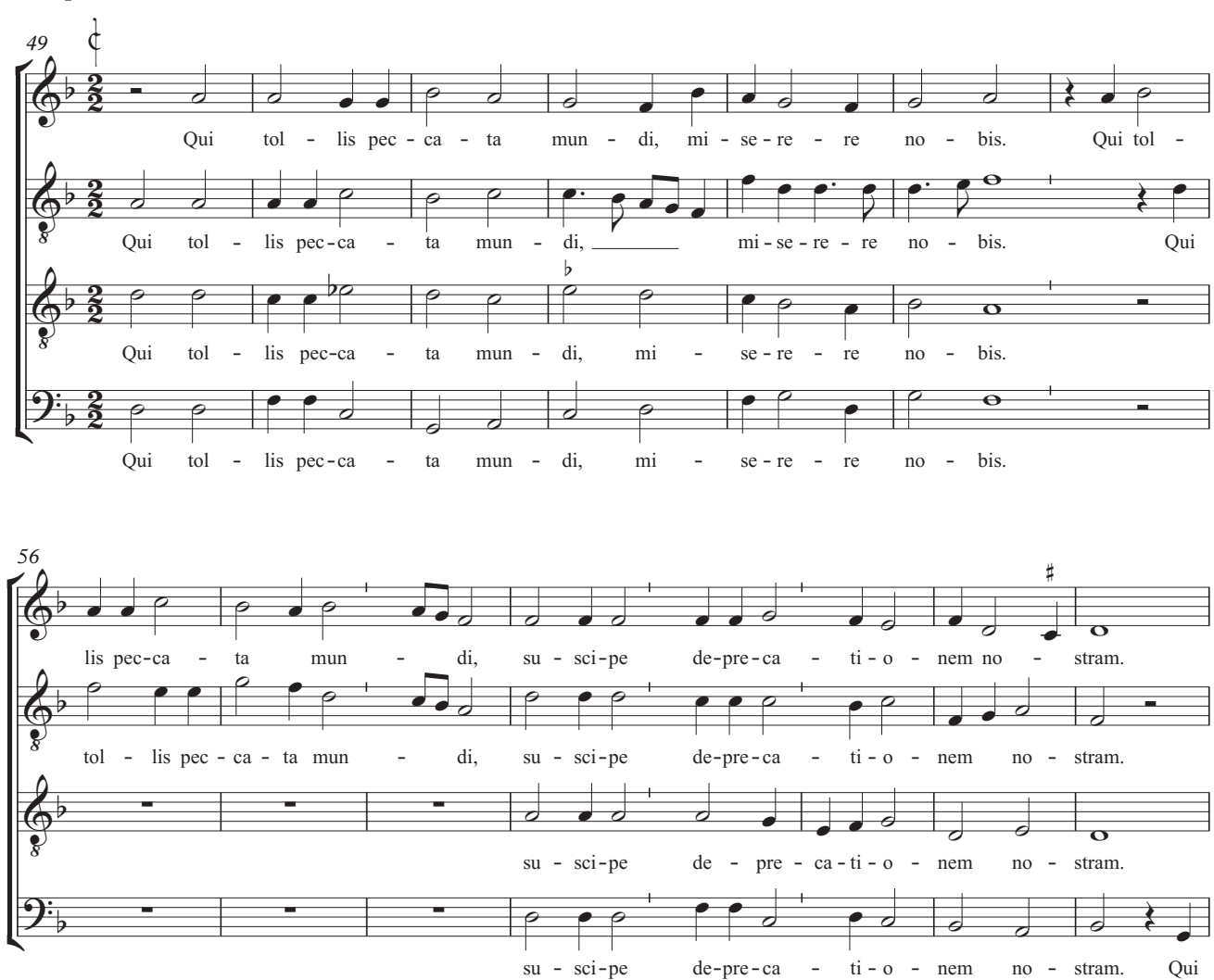

While similar compositional techniques are also found in the Credo, the parallels are somewhat less obvious in the phrase-by-phrase comparison, if only because the composer of the anonymous mass also incorporated two sections of chant (bb. $\mathrm{I}^{-} 5$ and $57^{-79}$ ). One notable detail, however, is the quick alternation of text between the paired duos, often breaking larger text phrases and separated by only a minim (see Example Ir.2). As is also seen in this example, both masses change into $\$ 3$ at the 'Confiteor'.

The alternating harmonies in homophonic/syllabic sections mentioned above form the first of several potential Gaspar stylistic fingerprints. ${ }^{45} \mathrm{~A}$ second feature is one voice acting briefly as a sort of long-note cantus firmus, even though it is not based on a pre-existing melody. In Gaspar's masses this happens regularly in the Sanctus, and especially at the beginning of the Pleni sunt and/or Benedictus. In the Pleni sunt of the Missa brevis, the altus has 
A New Mass and its Implications for Gaspar's Late Mass Style

Example II.I. (b) Gaspar van Weerbeke, Missa brevis, Gloria bb. 46-62
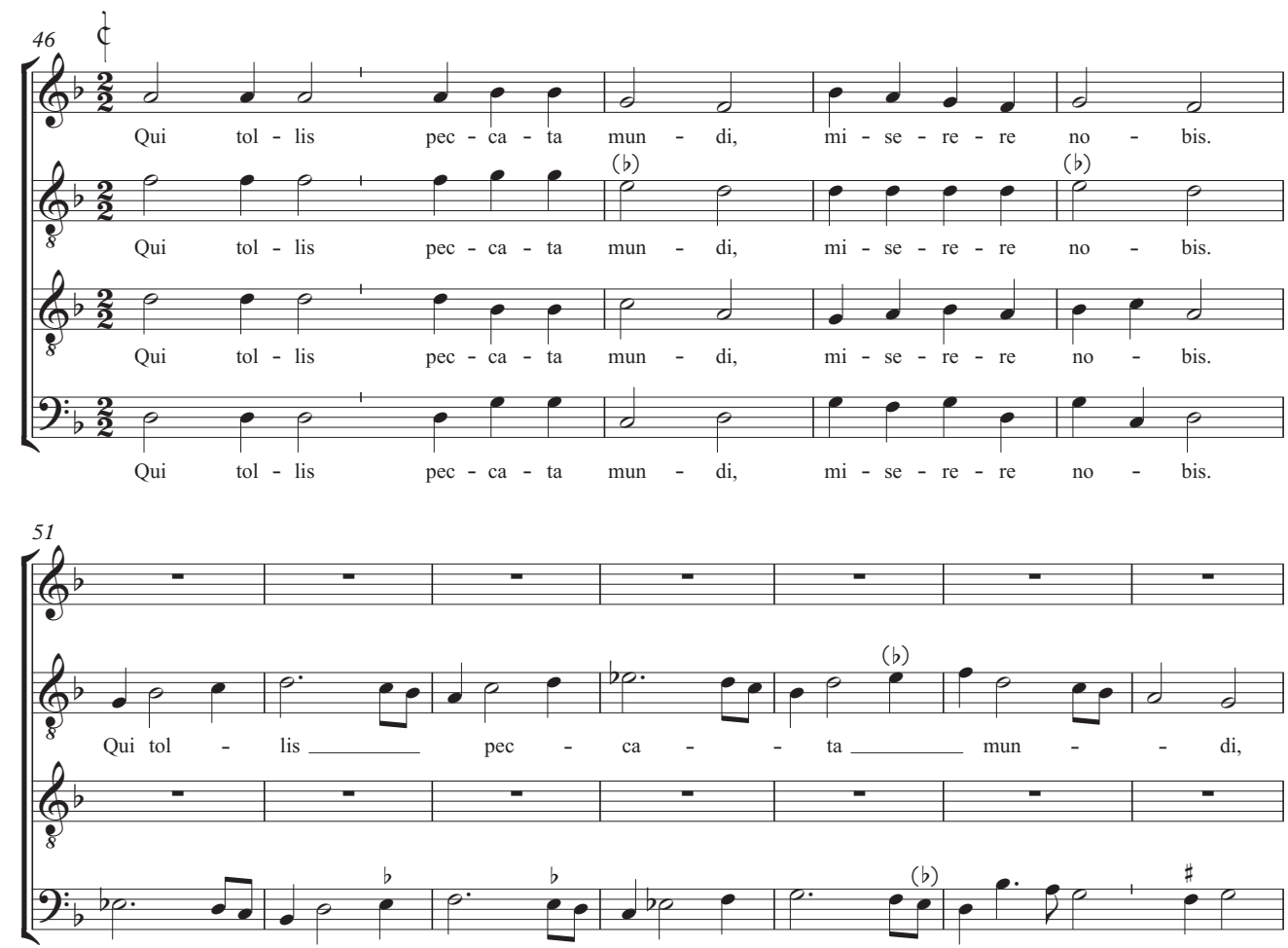

Qui
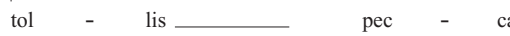

ta mun

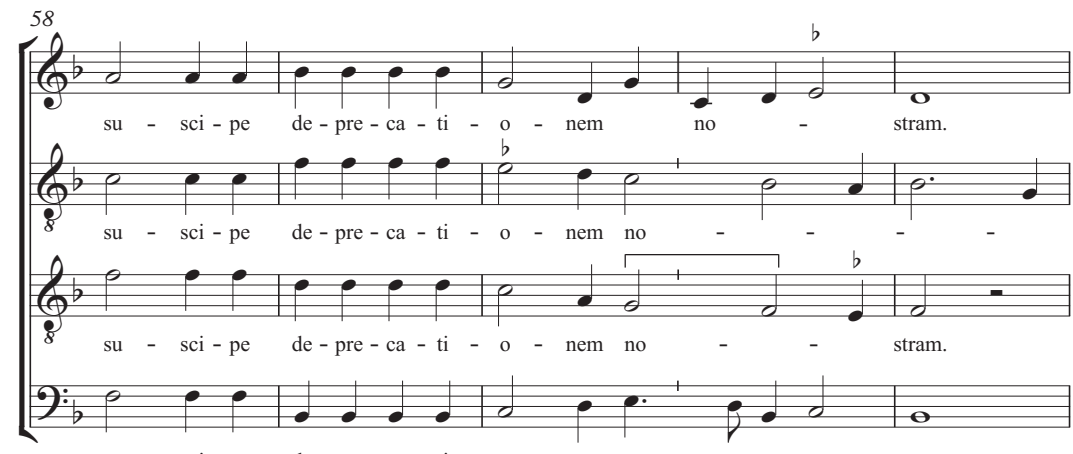

su - sci - pe de - pre - ca - ti - o - nem no - 
Example Ir.2. (a) Missa [sine nomine], Credo bb. I36-50
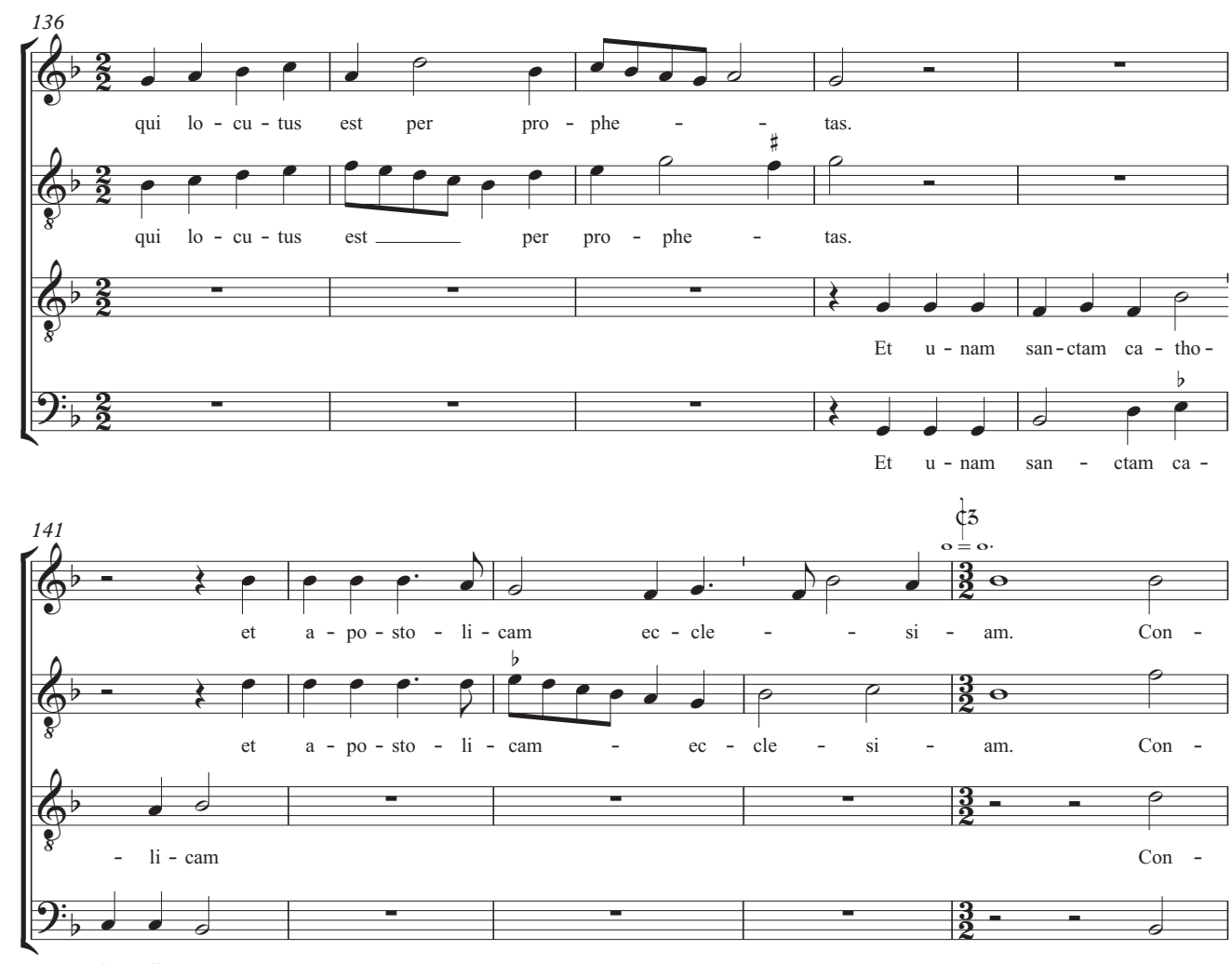

tho - li - cam

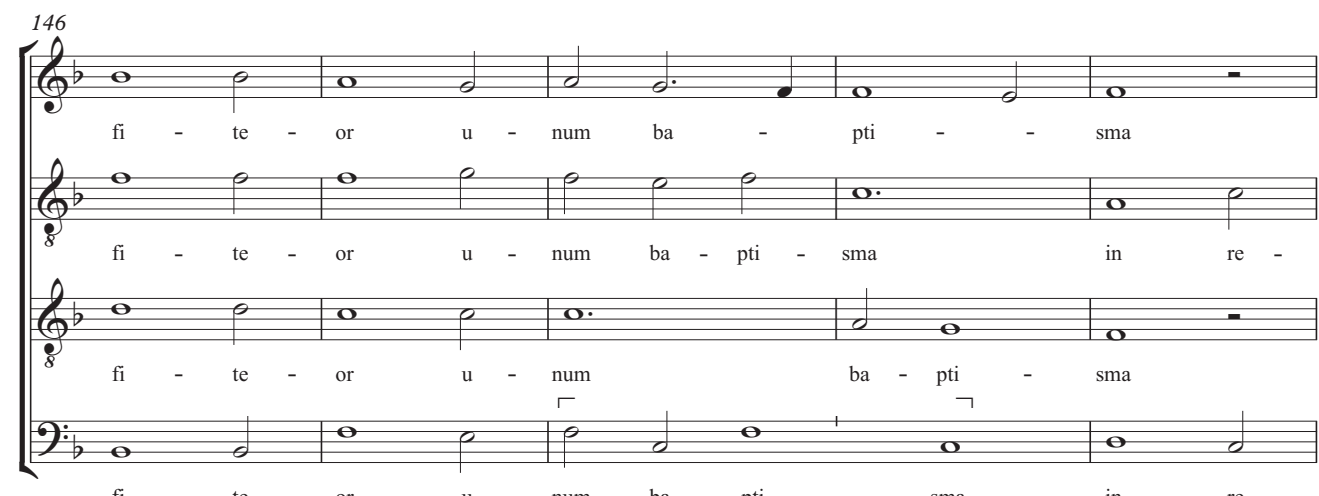


Example II.2. (b) Gaspar van Weerbeke, Missa brevis, Credo bb. 108-23
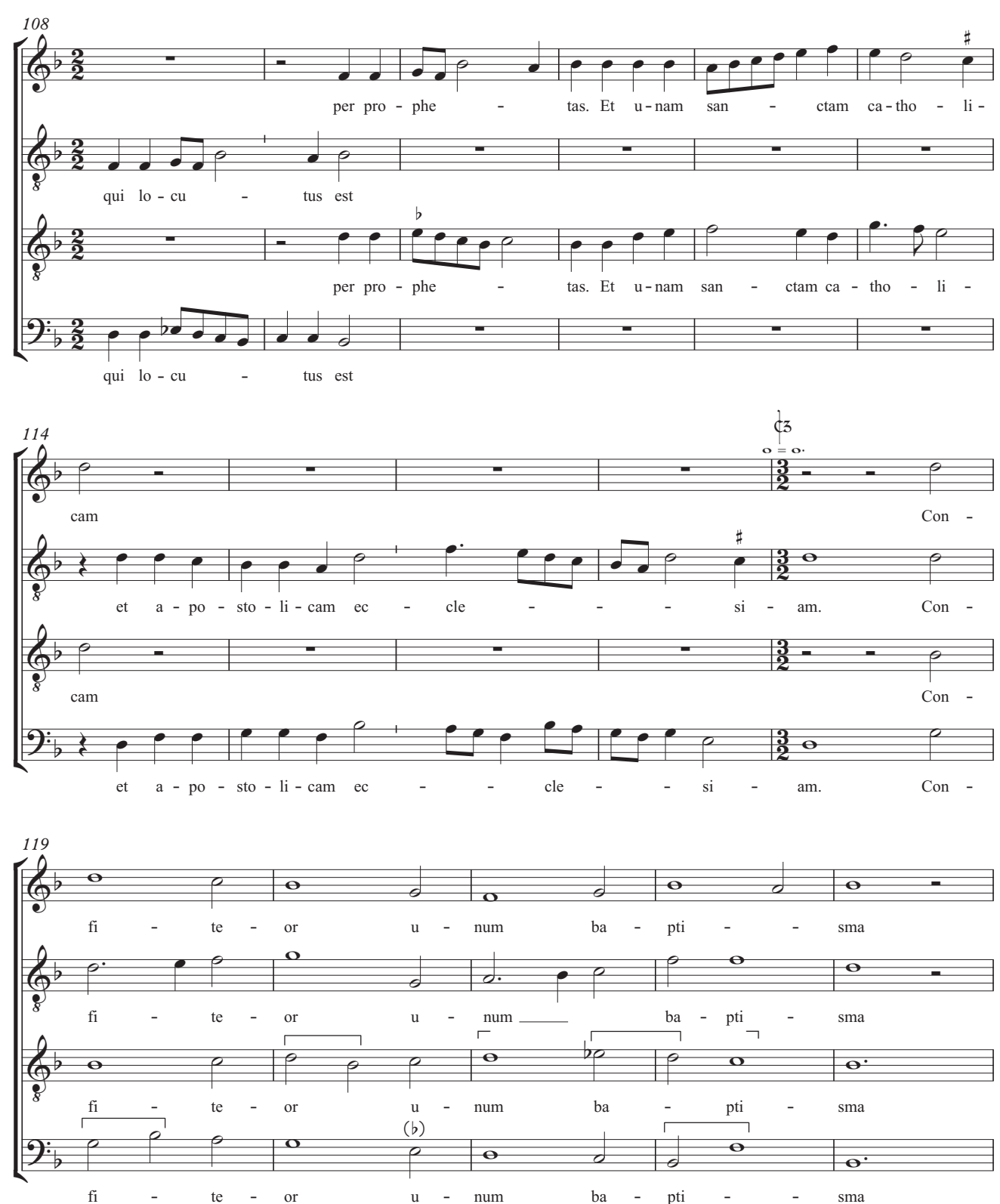


\section{Paul Kolb}

a long $\mathrm{D}$ and long $\mathrm{E} b$, resolving to the $\mathrm{D}$, while the superius plays around with minims and semiminims; their functions are then reversed in the following bars. At the same point in the anonymous mass, the tenor holds a $\mathrm{B} b$ for almost two longs, while the bass has an improvisatory line eventually leading to the cadence on G (see Example II.3). ${ }^{46}$ Related to this is the

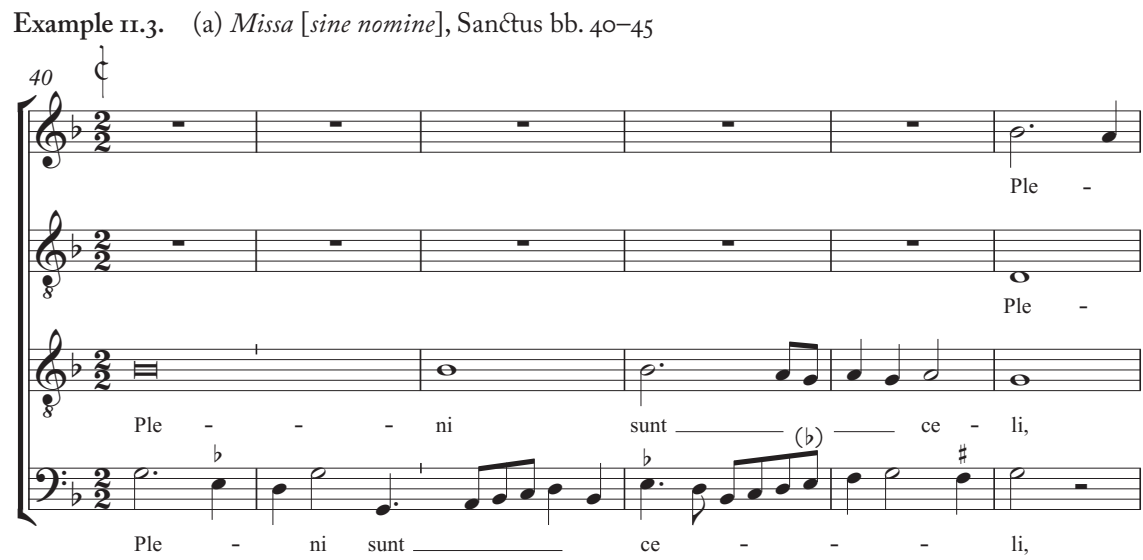

Example Ir.3. (b) Gaspar van Weerbeke, Missa brevis, Sanctus bb. 45-54
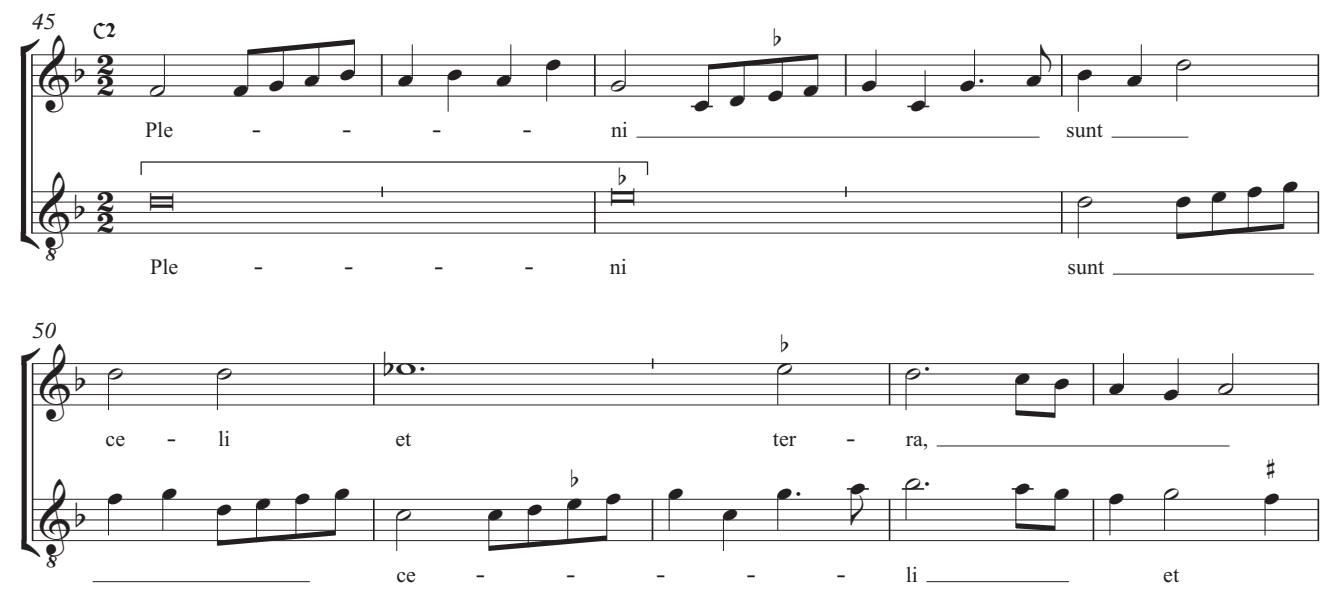

presence of imitation in two or three voices over a single extended sonority. In the anonymous mass, this occurs in the middle of the Credo; a comparable moment in the Missa brevis is the beginning of the Sanctus (see Example Ir.4). ${ }^{47}$

46 For other instances, see the opening of the Pleni sunt of the Missa Se mieulx ne vient, Sanctus, bb. 40-45; the Benedictus of the Missa Et trop penser, Sanctus, bb. $15^{-27}$; and the opening of the Sanctus of the Missa octavi toni, bb. I-I2. Jesse Rodin describes a similar feature in the Missa Princesse d'amourettes as having 'rhapsodic lines in the upper voices', though that example includes an actual, song-based cantus firmus; see Jesse Rodin, Josquin's Rome: Hearing and Composing in the Sistine Chapel (New York and Oxford: Oxford University Press, 20I2), I54, music example at I55.

47 This feature is related to what Rodin calls " $t r i a d i c$ " outlines', a practice especially cultivated by Gaspar; see Rodin, Josquin's Rome, I46-49. 
Example Ir.4. (a) Missa [sine nomine], Credo, bb. II5-18

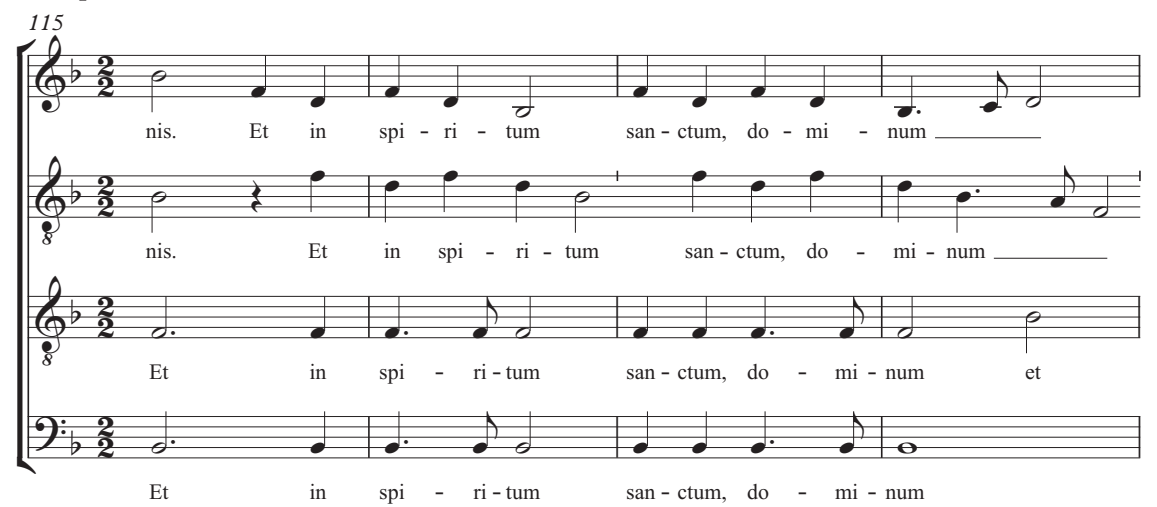

Example II.4. (b) Gaspar van Weerbeke, Missa brevis, Sanctus bb. I-5

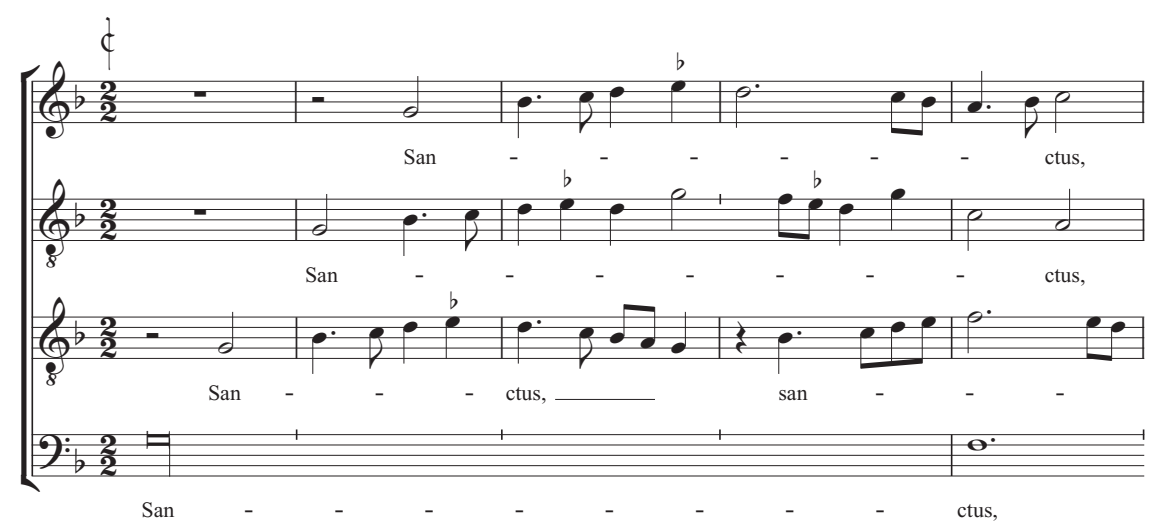

Despite the similar tonalities between these two masses, the voice ranges are not identical. Here the Missa brevis is somewhat of an outlier, with ranges in all voices approximately a third higher than in most of Gaspar's other masses. The anonymous mass uses the slightly lower ranges more common in Gaspar's music.

\section{A Cut-off Inscription}

All of this demonstrates that the anonymous mass exhibits many of the structural and stylistic elements common in Gaspar's other late masses. In addition, there is a fairly direct compositional relationship between the anonymous mass and the Missa brevis specifically. This could point either to Gaspar having been the composer, or to someone else having written this mass in emulation of the Missa brevis. But there is no third option: these two masses could not have been composed completely independently of each other. And the types and quantities of stylistic similarities probably point to authorship rather than emulation..$^{8}$

48 One can only speculate about which sorts of compositional similarities might point to emulation versus authorship. It is generally assumed that emulation involved both the mastery of a specific compositional style or genre as well as the desire to surpass it in some way. As discussed by Honey Meconi, when Josquin composed Nymphes des bois in homage to Ockeghem, the new composition was both modelled on the older 


\section{Paul Kolb}

But the most convincing detail concerning authorship is not analytical but scribal: a cut-off inscription on the bottom of the first page of the mass appears to name Gaspar as the composer (see Figure Ir.3). Saunders read this as 'Missa las... kyrie' and suggested that the second word refers to an unidentified model or liturgical occasion. ${ }^{49}$ But the second word is more likely to be 'Iaspar', potentially abbreviated to 'Iasp'. This would match the previous mass's attribution to 'iaspar'.

Figure II.3. Detail of Jena 2I, fol. IOI ${ }^{\mathrm{V}}$

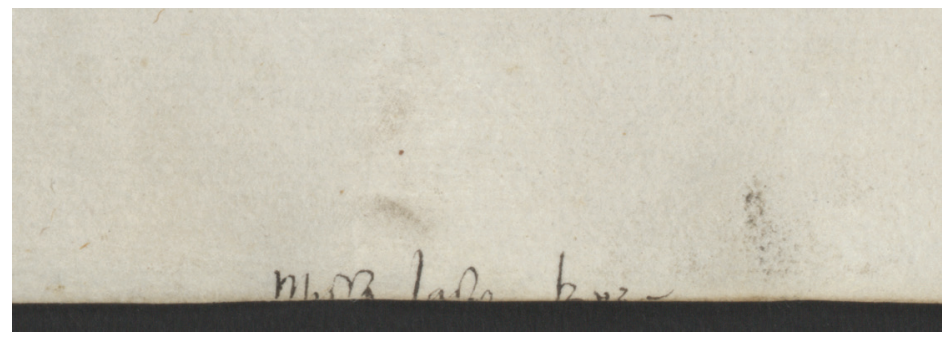

The manuscript is full of similar markings on the bottoms of pages, but most of them are simply a small line or loop of ink. Two additional more extensive inscriptions can be found on folios $43^{\mathrm{r}}$ and $88^{\mathrm{r}}$. While the lines and loops are found indiscriminately throughout the manuscript, all three of the more extensive inscriptions are found at the beginnings of masses: either on the blank recto before the first opening of the mass, or on the verso or recto of the first opening of the mass. It is impossible to say for sure, but the two loops on folio $88^{\mathrm{r}}$ (on the first opening of the Missa brevis) are also conceivably part of 'iaspar', not unlike the inscription for the anonymous mass (see Figure Ir.4). These inscriptions were probably written to indicate what the scribe should copy at these points in the manuscript. If so, the inscriptions preceded the copying of the music. After the masses were copied, they served no further purpose and could be trimmed off as necessary.

Figure II.4. Detail of Jena 2I, fol. $88^{\mathrm{r}}$

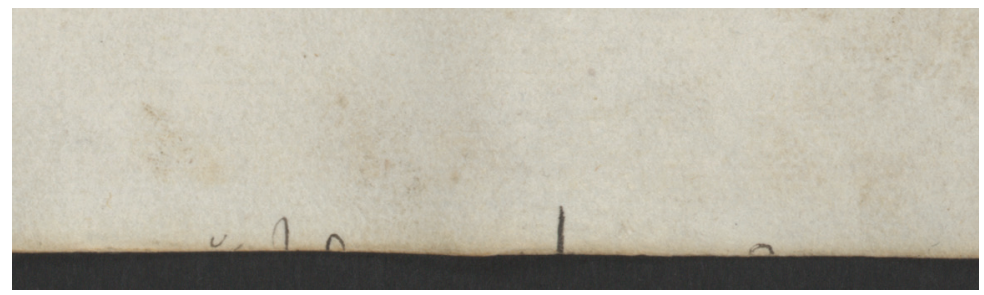

composer's Mort tu as navré ('recalls Ockeghem' and 'inverts Ockeghem's formal structure') while also trying to transcend the original ('outdoes Ockeghem'); see Honey Meconi, 'Ockeghem and the Motet-Chanson in Fifteenth-Century France', in Johannes Ockeghem: Actes du XLe Colloque international d'études humanistes, Tours, 3-8 février 1997, ed. Philippe Vendrix (Paris: Klincksieck, I998), 38I-402, quotes at 39I. Of course, this does not have to be the case. But the types of formulaic similarities here suggest that they have been internalized by the composer rather than being intentionally parodied. Equally, there is no apparent desire to have stylistically distinguished the 'new' composition from the 'original'.

Saunders, 'Anonymous Masses in the Alamire Manuscripts', 66-67. 
When I first began to transcribe the anonymous mass at the end of Jena 2I, I was struck from the first Kyrie that this could be Gaspar, and the impression grew with each subsequent movement. The arguments which I built to support this impression thus did not stem from a completely neutral analysis. But musical impressions, if sometimes elusive and ephemeral, are nevertheless valuable, and in this case they were eventually reinforced by scribal evidence.

For Gaspar, at the risk of being somewhat circular, this mass helps to confirm a certain compositional narrative. As a younger, ambitious composer, his output consisted of masses which are virtuosic and striking if more traditional: all qualities which make them ideal repertoire for the papal chapel. Later in life, well-established as one of the top composers of his generation, his masses were simpler, shorter, sometimes approaching the pedestrian, but increasingly containing stylistic aspects and compositional features unique to him.

If these masses—the Missa N'as tu pas, the Missa brevis, and the Missa [sine nomine]should then be added to the repertoire of 'missae breves', the implications are less clear. One the one hand, the transmission of all three is completely independent of Milan (as well as, for the most part, Rome). On the other hand, while there are stylistic similarities to the other Missae breves, they are on the whole less extreme: less short and less uncomplicated. When taken together with the other Missae breves, they appear as less of a locally defined subgenre and more of a wide-ranging spectrum, probably reflecting compositional trends (both in Milan and elsewhere) towards a style of composed polyphony that could be performed more regularly and by a wider range of singers and choirs. But for Gaspar, in the twilight of his glistening career, if there was a specific reason for the composition of masses of this sort, it remains a mystery. 
